\title{
Management Fads: The Seeds of Change
}

\author{
Donna J. Evanecky, JoDell Steuver \\ Purdue University College of Technology
}

Kokomo/Columbus-SE Indiana

\begin{abstract}
America has long been a country ripe for the planting of seeds of change - our culture cultivates change and provides a fertile environment for their growth. The paper talks about the life cycles of management fads - new growth, over sowing, sprouting of imperfectly implemented ideas, good ideas choked with the weeds of disenchantment, and abandonment of the field. It will also examine why people adopt fads and present some recent management trends.

Paper

In the March 4, 1985, issue of Industry Week, Harvey Gittler wrote a short article entitled "One More Panacea and We'll All Go Nuts." In this article, he covers the sixties, seventies, and a portion of the eighties. Near the end of the article, he states, "there is no doubt that great advances and improvements have been made over the last 30 or 40 years. Fads - a fleeting collection of beliefs - continue to be disseminated by management trendsetters in the twenty years since Gittler wrote his comments. Peter Scholtes says we live in an era of "management pathology."1
\end{abstract}

But why is each technique heralded as a panacea? One answer to the question is that management is "faddish" - companies want to be seen as trendsetters. If a fad improves the bottom line, usually within the next quarter, the company will drive it home. Fads are touted as a way to improve organizational effectiveness. These interventions give hope of improved performance.

Robert Bacal allows that two kinds of people are readily attracted to management fads. One type is the person who is attracted to information on management, who has the time, desire and commitment to digest a new concept. These managers can apply the information and succeed. The other type of early adoptee is the person familiar with the buzzwords, who really would like to seem on the cutting edge, but who does not have enough depth of knowledge to apply the concept and make it work. ${ }^{2}$

The perennially favorite yo-yo is a good example of this concept. An expert demonstrates tricks that look so easy. Yoyos colorfully advertise the fun all have been longing for, and they are relatively inexpensive. Every kid on the block now has a new yoyo, but about 20 percent of them can actually make the yoyo work. About once a decade a new model is introduced and marketed, ensuring that many American homes have these toys in the closet. 
The gurus

As long as management gurus keep the fads coming, and there is no shortage of ideas, companies will try them. The management fad industry has remained one of the world's largest and has continued to grow over the past two decades with a typical life cycle of a few years ${ }^{3}$. Just as the toy industry markets aggressively, the management gurus have marketed or been marketed aggressively. Almost every management fad has a guru - a high profile proponent who can speak vigorously for the technique. Testimonials are powerful in convincing others to adopt the latest management fad.

The reputable promoter helps spread the word and makes the information accessible. Tom Peters and Stephen Covey are some of the best in promoting an entire line of products. Other sources of fad promotion include business schools, consulting firms, and mass-media productions. $^{4}$

Dr. W. Edwards Deming's successes in Japan finally garnered American interest in his theories. The success of the Japanese economic recovery after World War II and the change in the quality of Japanese-produced goods caught Americans' eyes. While Americans enjoyed a cushy margin in trade in the early 1950's, it soon became discernable that Japanese goods were disturbing American markets. Engineering management became part of the quality revolution when Japanese parts and products began to cut into the U.S. trade balance. By 1980, U.S. automotive makers were embarrassed by the NBC documentary If Japan Can, Why Can't We? Deming was insistent that the answer to this question lay in management. ${ }^{5}$

Deming asserted that variability exists everywhere in everything. He taught that the real question is what does this variation mean? His principles urged management to begin seeing and managing the entire company as a system. He demonstrated in his lectures that the production of individual workers could be no better than the system. Deming believed that every aspect of the organization under good management contributed toward system optimization. He saw divisions working together in a win-win collaboration. Deming likened successful organizations to a human body — one that depends on all of the parts to be identifiable and functional as a body. ${ }^{6}$

Deming believed in cross-disciplinary problem solving. He introduced sound scientific processes to manufacturing, and influenced the development of the American Supplier Institute. Deming's theories created a "scientifically reason for reenlisting the brains of workers to solve production problems." 7 Workers learned to use control charts to monitor process limits and reduce variation. His quality concepts were widely distributed through the big-three U.S. automotive companies and the Department of Defense. Statistical process control helped these major buyers to obtain parts that met tighter standards and lower scrap and waste in their business processes. The Deming method was the beginning of thinking of both engineering and business problems as statistical problems.

Tales from the trenches

Deming pleaded with organizations to substitute leadership for quotas. He opposed management by objectives because he felt that a numerical focus neglected a systemic viewpoint. Recent 
experiences of a major mail-order garden products company reinforce Deming's thinking. It provides an example of the bad things that can happen to good intentions and good procedures when management's understanding of novel management practices barely scratches the surface of a trend. The failure of managers to invest in in-depth learning can make good theory faddish when misunderstood engineering management practices are weeded out too soon.

The company wanted to increase sales by featuring a list of "specials" that would be offered to phone-order customers. Call center operators were to be paid an incentive for each item sold from the list, if they sold a minimum of 10 items in a week's time. Many operators worked less than 40 hours a week, so their opportunities for sales varied. Those who worked customer service lines not only had to neutralize an angry or disappointed customer, but then develop a relationship for a sale opportunity. The bonus of an additional $\$ 5.00$ a week wasn't much of a motivator for these operators. Since the bonus possibility didn't yield many additional sales, operators were next threatened with demerits if they did not meet the weekly quota of 10 additional items.

A group within the company began to petition for a union. The vote would be taken during the peak sales season. The garden store then devised sales contests, holding a competition among teams of operators. Operators were assigned to teams by management. Very few of the operators knew other team members, nor were they introduced to their team members. The team that won enjoyed nice gift bags of various products, but there was no team development to sustain the effort. The teams were never mentioned again after the contest ended and the union was voted down.

The company finally hit upon a winning strategy to increase sales. The featured "specials" continued to be used. Calls were monitored against a checklist to improve customer service. The checklist was available to operators as they interacted with customers. This system provided for verification of names and addresses, verifying order items, quantities, and shipping preferences. The "specials" were offered at the close of the call along with thanking the customer for his business. Operators were monitored three times each week. Operators were given the opportunity to listen to tapes of their own calls and perform their own evaluations. The employee evaluation and sales coach's evaluations were compared and agreed upon. Selfimprovement and teaching became part of self-leadership as operators wanted to learn more about products and tried to provide better customer service. The garden company began its first steps toward a measured focus on the customer.

Unfortunately, the company neglected to view the entire organizational system. When sales promotions began orders were being hand-picked and packed. There was very little automated product handling equipment. After the hand-driven system couldn't support the increase in sales, the company began to invest in automated product scanning, picking and packing. Vendors who drop-shipped goods were not required to update company databases on product availability, so only product that was physically present in the warehouse showed accurately in the inventory. Sales center operators could not respond to customers' questions about availability of product. It became quite obvious that sales, engineering and purchasing management needed to be working together to support internal and external customers. 
Influences on fad adoption

Several factors favor the adoption of management fads. The organization's culture is an important part of this formula. Companies with a culture of risk taking are fertile for the planting of new ideas. Those with frustrating past experiences will adopt different fads. Often organizations want to set themselves apart by adopting management innovations, and there is no denying that fads can create excitement and energize a tired workforce.

An example of an energizing fad has been the business parable such as Who Moved My Cheese?, The One Minute Manager, Fish!, and Gung Ho. A catchy title gets people's attention; the books present recognizable business characters and cases in humorous stories. These books do encourage us to laugh at our fears, focus on relationships at work, rid ourselves of toxic energy, and foster high morale. Fish! encourages creativity and fun at work and makes the case that work that is enjoyable is meaningful work. Their weakness, like that of the StayPuft Marshmallow Man, is they can be roasted by their limitations - it is hard to develop depth of theory in 90 large-print pages.

According to the U.S. Central Business Research Bureau, half of all business product launches are ensured success with a snappy name. ${ }^{8}$ Who Moved My Cheese? has prompted Who Cut the Cheese?, Who Stole the Cheese?, The Stinky Cheese Man and Other Fairly Stupid Tales, and Nobody Moved Your Cheese. What do these products have to deliver after the hour it takes to read them? Is their advice sound and scientific?

The jacket cover of Who Cut the Cheese? says it all, "a...fable to encapsulate the fundamental rule of modern American management and the new economy: "Survive change by shifting the blame." Hype alone can't sustain a fad. The book stinks worse than limburger.

Many fads die because they have no substance. Such fads do not allow tailored adoption or much imagination in their application. People tire easily of trite phrases and shallow theories. Sometimes there is no opportunity for repeat sales. Other fads die because there is a surplus of product, so the desired knowledge or item is no longer available to just a few. The concept or product loses its status and price advantage.

Change that happens rather suddenly on the strength of the most minor input are the subject of The Tipping Point. Fads may have what Malcolm Gladwell calls the "stickiness" factor. 9 "We may remember a catchy phrase long after the product is gone. Who can forget, "Where's the beef?"

Sometimes there are external forces that cause organizations to embrace fads. Dynamic and turbulent environments dictate change. Regulatory and political environments impose adjustments and necessitate innovation. An increase in union activity often enlarges management approaches. Competition may be the universal joint of change. Whatever the external pressure, organizations are prodded to think and discuss the effects these conditions command.

Innovation and affliction 
A consultant told his story of working with a major bank to develop a more creative workforce. The bank president had been talking to a manager from Proctor and Gamble about the creativity training their research and development department had attended. The bank was a prominent institution, and it seemed like creativity training would be good for them, too. On the first day of the creativity training, the executive vice president started the meeting by emphasizing how important the concepts would be for the bank to meet the changing climate in banking laws, regulations, and need to increase revenue from service sources. The vice president remained in the training for the first fifteen minutes and never returned during the three-day session. The mixed message that the vice president sent by his absence was just the beginning of the tribulation.

The bank had chosen their executive suite for the training, a place most middle managers had never visited. The culture of the organization contrasted wildly with the consultant's chosen attire. His Mickey Mouse ${ }^{\circledR}$ t-shirt with the slogan "up yours" did not match the conservative and elegant ambiance. The consultant had intended to make the point that play is important to foster creative thinking. He began by alienating part of his audience.

Bank employees have a habit of following rules and procedures. Bankers tend to solve problems in terms of there being only one right answer. In order for the consultant to get the trainees to develop the habit of divergent thinking, the group had to examine why they followed certain rules and procedures. The group was forced to examine the validity of these processes. It took quite some time for them to open up and admit that there might be two legitimate ways of performing a task.

A large number of left-brain thinkers were starting to feel very uncomfortable in a world of possibilities, ambiguity and risk taking. The consultant was frustrated with his inability to make great strides in three days, concluding that his efforts had been a waste of time. Probably both the consultant and the bankers lacked the structure and processes necessary to talk about the pressures that were going to necessitate a more creative approach to generating revenue. No one had much fun at work that week, and the effort was an expensive enterprise for the bank. Creativity training left a bitter aftertaste in everyone's mouth, and the vice president was embarrassed by his surface understanding of the creative process.

Engineering systems and chaos

Margaret Wheatley brought parallels from the natural world to the attention of the engineering world with her imagery that acknowledges complexity. The systems approach to management accedes that systems are dynamic and self-evolving. Wheatley refers to the equations Lorenz identified in a 1963 paper, later known as the butterfly effect, as the essence of chaos. The amount of difference in the starting points of the two curves is so small that it is comparable to a butterfly flapping its wings, but these differences will become amplified eventually to change the large scale atmospheric motion, so that the long term behavior becomes impossible to forecast. ${ }^{10}$ While Wheatley and Gladwell write in different metaphors, they both acknowledge the influence of barely perceptible events on complex systems. 
Corrie ten Boom and her sister Betsie experienced the unexplainable wonders of nature in their prison camp environment. The fleas that heavily infested their barracks at Ravensbruck prison camp were the very things that kept the guards from entering the barracks. Vermin allowed the sisters to conduct religious studies without interference, providing emotional comfort and harmony in housing built for 400 , but occupied by $1400 .{ }^{11}$ Perhaps their story is one that Wheatley and Deming hadn't read, but it illustrates the "smallest things" idea of influence on systems.

While sociotechnical systems have been studied since World War II, the idea of the propensity of a system to be sensitive to initial conditions; therefore, unpredictable is an idea that has been passed from the arena of mathematics and meteorology to management. In management terms, small and insignificant incidents can set of a chain of events with far reaching consequences.

Chaos theory changes the scale of thinking about management. We no longer see people as cogs in the industrial machine, but we are beginning to see organizations as living systems. The fear of chaos needs to be tempered with patience as relationships within a living system are explored. Wheatley says that chaos - discomfort — will eventually make members of an organization let go of what they know and do routinely. The transformation of an old system will depend on the ability of the organization to share information abundantly. Death comes to an organism when it can no longer change.

Systems thinking considers the process of self organization. In this natural phenomenon of self organization "the development of new structures takes place primarily in and through the system itself." ${ }^{\prime 2}$ There are examples in nature of self-organizing systems. Perhaps the most studied of these simple systems is magnetism. As the tiny little magnets in a potentially magnetic material warm, they are excited and move randomly. As the material cools, the little magnets or "spins" align themselves, producing a strong magnetic field. ${ }^{13}$ Systems thinkers in the management arena propose that self organization also takes place in human organizations under the right environment and conditions. It is the engineering manager's job to provide the climate for new systems to evolve through encouraging new ideas, developing an acceptance of change and tolerating failure. $^{14}$

Change in management thinking has evolved from an organization as a structure of technological innovation to a process of technological innovation. The process of technological innovation takes on the dynamics of international transfer of innovations and the national systems involved in transfer. As organizations expand to the global arena, communications with customers allow them to move to a partnership level. Robert Rosen reminds us that the culturally literate leader must be a proud citizen, an inquisitive internationalist and a respectful modernizer--qualities that will build transfer of technology and innovation. ${ }^{15}$

Engineering managers are not isolated from the socio-technical environments in which they work. Decision-making processes in engineering examine costs, benefits, trade-offs, alternatives, needed performance, wanted performance and other factors. Many times the easiest decisions are those that are quantifiable. The cultural climate created by management trends can negate quality and process improvements. 
Influences on fad adoption

While there are those organizations who adopt fads to be seen as leaders, there also are those who adopt fads to emulate leaders. Embracing fads may be necessary to collaborate with suppliers or clients who have adopted certain management systems. There might be sanctions if an organization does not accept a management fad. Peter Clark comments "innovation is seen as positive, easy to adopt, a matter of best practice, linear, and suppliers as neutral."16 This may be an optimist's naïvete, but this embrace of openess also allows organizations to remain competitive.

Pressures to conform also come from knowledge cascades - serial decision making. One person decides to adopt a fad, then another, and then finally everyone adopts the fad because of decisions made by predecessors. In some cases following the leader may not be the best path to take, because the pre-selected tool does not meet the repair needs of all. Organizations that are highly centralized and controlled are more likely to trigger a knowledge cascade. These kinds of fad adoptions are similar to group think. Being the leader or first in a fad is a much better position to take. ${ }^{17}$

Fad cycles begin with discovery of a new idea and typically proceed to wild enthusiasm for the trend. People begin to digest and discuss the information presented in the management fad, applying it if it seems to fit a need. Eventually there is disappointment and abandonment. Some management trends like total quality management have had a forty-year run, while quality circles lasted about a decade. Many times one fad capitalizes on another-educational experiences have taken children through phonics, phonemes, sight reading, color-coded reading, whole language instruction, balanced literacy and more. ${ }^{18}$

Should an organization adopt a fad? The public perceives companies that adopt fads as more innovative. A study of the 100 largest industrial corporations, based on the 1995 Fortune database, showed that organizations that were closely associated with popular management fads were perceived to have better managers. ${ }^{19}$ Fads may win public admiration for organizations, and this may contribute to a positive bottom line. Americans seem to have a positive attitude toward change.

For the company considering fad adoption, it is critical to develop both measures for the fad and channels to communicate with everyone in the organization. Measuring the right things influences success. If key measures are not identified, people will be led astray. Organizations that can clearly identify their core businesses and adapt their focused strategies to emerging trends can benefit from new management thinking. Communication up and down the organization keeps everyone informed about the changes taking place. Both internal and external stakeholders need to know what the new strategy will be. ${ }^{20}$

The death of a fad comes is influenced by several things. One is the chaos principle that the organism can no longer change. Barbie adapts well to change with a website, games, fashion tips, a new outfit, new ethnic identity, new hair, new accessories, or new boyfriend. There is always a new group of young girls waiting in the wings. Barbie seems to interest girls between the ages of 3 and 12 - a relatively long span of appeal compared to some other toys. ${ }^{21}$ 
Perhaps project management will be one of the fads that will be incorporated into business culture. Ideas with merit seem to find their way into engineering practices. Those who can use project management tools not only for individual projects, but for the entire project management process will ensure its longevity. Once a fad moves from novelty to a position central to a business's corporate strategy, it becomes a strategic business tool. ${ }^{22}$

Thoughtful, reflective study is called for from today's leaders. Conscientious engineering managers do a great deal of reading from several sources, critically evaluating the merits of a popular management trend. Persistent, critical examination of management trends can shape management understanding of themselves and their organizations. ${ }^{23}$ Not every single piece read may fit the organization's needs, so managers can choose pieces that fit. ${ }^{24}$ Organizations who don't have time to do the homework on fads might find the lone dissenting voice of Dilbert in The Dilbert Principle: A Cubicle's-Eye View of Bosses, Meetings, Management Fads \& Other Workplace Afflictions just what they need.

\begin{tabular}{|c|c|c|c|}
\hline Management Fad & ${\text { Life } \text { Cycle }^{2}}^{2}$ & Pros & Cons \\
\hline Quality Circles & 1977-1986 & $\begin{array}{l}\text { Three heads generate more ideas } \\
\text { than one. } \\
\text { Many of these processes have } \\
\text { evolved into management } \\
\text { practices. } \\
\text { Feedback and data are important } \\
\text { management tools to solve } \\
\text { problems. }\end{array}$ & $\begin{array}{l}\text { Workers didn't understand basics of } \\
\text { TQM. } \\
\text { Leadership needed to be developed for } \\
\text { Quality Circles to be effective. } \\
\text { Americans are individualistic, and } \\
\text { they weren't used to working in } \\
\text { circles. }\end{array}$ \\
\hline TQM Management & $1990-2001$ & $\begin{array}{l}\text { Best practices can be shared and } \\
\text { modeled. } \\
\text { TQM can provide real cost } \\
\text { savings. } \\
\text { The approach is data-driven and } \\
\text { searches for root causes of } \\
\text { problems. }\end{array}$ & $\begin{array}{l}\text { These practices must occur within a } \\
\text { larger framework. } \\
\text { Rigorous mapping of processes is } \\
\text { required. } \\
\text { The program needs to pay its way } \\
\text { quickly. } \\
\text { Training is required. }\end{array}$ \\
\hline $\begin{array}{l}\text { Business process } \\
\text { re-engineering }\end{array}$ & $1985-2000$ & $\begin{array}{l}\text { Successful companies rethought } \\
\text { entire business models. } \\
\text { Cleaning the slate enables } \\
\text { people to examine processes in a } \\
\text { new way. } \\
\text { The name was simple. }\end{array}$ & $\begin{array}{l}\text { The consultant always wins. } \\
\text { It required companies to expand their } \\
\text { computer capacities. } \\
\text { Middle management was the big loser } \\
\text { in this movement. } \\
\text { Companies lost brain power. }\end{array}$ \\
\hline $\begin{array}{l}\text { Knowledge } \\
\text { management }\end{array}$ & 1991 - ???? & $\begin{array}{l}\text { This fad is now becoming part of } \\
\text { standard business processes. } \\
\text { Maybe it isn't a fad at all, but a } \\
\text { process of discovery, creation of } \\
\text { knowledge, dissemination and } \\
\text { utilization of that knowledge. } \\
\text { Today knowledge is seen as a } \\
\text { tradable asset. }\end{array}$ & $\begin{array}{l}\text { There are indeed challenges to } \\
\text { sustaining momentum in learning } \\
\text { organizations. } \\
\text { Knowledge center concepts have faded } \\
\text { away as knowledge networks emerge. } \\
\text { There is some implication that } \\
\text { managing knowledge is focused on } \\
\text { what one knows rather than creating } \\
\text { new knowledge. }\end{array}$ \\
\hline Systems management & 1992 - ???? & $\begin{array}{l}\text { The revision of systems } \\
\text { management and inclusion of } \\
\text { chaos theory continues. } \\
\text { Prevention is the focus of } \\
\text { systems management - fixing on }\end{array}$ & $\begin{array}{l}\text { Can't be implemented without } \\
\text { proactive leadership. } \\
\text { Requires a great deal of collaboration } \\
\text { and teamwork. } \\
\text { Measurement systems and parameters }\end{array}$ \\
\hline
\end{tabular}

Proceedings of the 2005 American Society for Engineering Education Annual Conference and Exposition Copyright 2005, American Society for Engineering Education 


\begin{tabular}{|l|l|l|}
\hline & $\begin{array}{l}\text { the front end through sound } \\
\text { systems design. } \\
\text { Organization must determine } \\
\text { what the price of } \\
\text { nonconformance is. } \\
\text { Replacement of subjectivity by } \\
\text { measurable requirements. }\end{array}$ & $\begin{array}{l}\text { are paramount to success. } \\
\text { Organization has to measure the right } \\
\text { things and use the right parameters. }\end{array}$ \\
& & \\
& & \\
\hline
\end{tabular}

Bibliography

1. Scholtes, P. R. (1997). A thoughtful, literate leader. Quality Digest. QCI International. $\mathrm{http}: / / \mathrm{www}$.qualitydigest.com/april97/html/cover.html retrieved on January 2, 2005.

2. Bacall, R. Management fads: things you should know. http://www.work911.com/articles/mgmtfad.htm retrieved on October1, 2004.

3. Ponzi, L. J. \& Koenig, M. (October 2002). Knowledge management: another management fad? Information Research, 8, 1. http://informationr.net/ir/8-1/paper145.html retrieved on January 2, 1995.

4. Ponzi, L. J. \& Koenig, M. (October 2002).

5. Gabor, A. (1990). The Man Who Discovered Quality. New York: Penguin Books

6. Deming, W. E. (July 1996). The New Economics, 25-65.

7. Gabor, A. (1990). 58

8. Barry, M. Succeeding in business through marketing fads. Retrieved February 2, 2005, from www.maxbarry.com/writing/bits/marketing.html

9. Gladwell, M. (2000). The Tipping Point: How Little Things Can Make a Big Difference. Little Brown.

10. Flower, J. (1993). The power of chaos: excerpts from an interview with Meg Wheatley. The Healthcare Forum Journal, 36. Retrieved December 24, 1994, from

http://ww2.sjc.edu/faculty_pages/rdegray/SystemsThinking/NECSI2002/Session10.html

11. Ten Boom, C. (1971). The Hiding Place. New Jersey: Spire Books, 188-206.

12. Heylighen, F. (January 27, 1997). Principia Cybernetica Web. Retrieved January 2, 2005, from http://pespmc1.vub.ac.be/SELFORG.html.

13. Heylighen, F. (December 2, 1999). Magnetization and Bénard rolls: examples of self-organization. Retrieved January 2, 1995, from http://pespmc1.vub.ac.be/SELFOREX.html.

14. Ivancevich, J., Lorenzi, P., Skinner, S., \& Crosby, P. (1994). Management: Quality and Competitiveness. Burr Ridge, Illinois. Irwin, 609.

15. Segil, M., Goldsmith, M., \& Belasco, J. (2003). Partnering: The New Face of Leadership. New York: American Management Association, 170-176.

16. Shepard, J. (October 2003.) Peter Clark: Organizational Innovations - book review. Retrieved January 1, 2005 from http://www.findarticles.com/p/articles/mi_m4339/is_8_24/ai_111027981/pg_2. 
17. Downes, S. (December 23, 2004.) Cascades and connectivity. eLearn Magazine. Retrieved January 1, 2005, from http://elearnmag.org/.

18. Carnine, D., Silbert, J. \& Kameenuii, E. J. (1997). Direct Instruction Reading $\left(3^{\text {rd }}\right)$. New York: Merrill.

19. Shiemann, W. \& Associates. (1996).

20. Pierce, J., \& Newstrom, J. (2005). What really works: the $4+2$ formula for sustained business success. The Manager's Bookshelf. New Jersey: Pearson Prentice Hall, 112-113.

21. Retrieved February 1, 2005, from http://www.barbie.com .

22. Riznic, J. (Mar 2004.) Engineering Management Journal. Rolla: 16, 1,50.

23. Collins, D. (April 16, 2003). The branding of management knowledge: rethinking management "fads". The Journal of Organizational Change Management, 16, 2. Emerald Group Publishing, Ltd..,186-204(19)

24. Turk, W. (September-October 2004). Management fad of the month: can they all work? Defense A T \& L. http://www.dau.mil/pubs/dam/09_10_2004/tur-so04.pdf retrieved on December 23, 2004.

\section{DONNA EVANECKY}

Donna Evanecky started teaching as an assistant professor for Purdue University School of Technology in 2001 after an eight-year career in the field of quality management. She teaches Organizational Behavior, Managing Change, Leadership, Entrepreneurship, Occupational Health and Safety and Team Development for the Department of Organizational Leadership and Supervision at the Kokomo campus.

\section{JODELL STEUVER}

JoDell K. Steuver is an Associate Professor in the Department of Organizational Leadership at Columbus, Indiana. She was a member of the Association for Quality and Participation for many years and has taught in automotiverelated industries for six years. She is currently teaching team development and safety courses. 